\section{Scientists must be able to report without censorship}

SIR - Government scientists must be able to research and report their findings to the public without fear of censorship or intimidation. We need honest results from our science agencies that we can count on. And taxpayers have the right to know the facts.

But in recent weeks, the press has reported allegations that scientists at NASA and the National Oceanic and Atmospheric Administration (NOAA) are routinely silenced when reporting their findings on climate change ( ${ }^{\alpha} \mathrm{US}$ scientists fight political

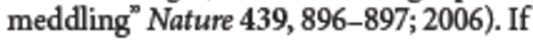
true, this is unacceptable.

That's why I've called for the Government Accountability Office to review the policies and practices of our federal physicalscience agencies to ensure openness in communication of their science results. This includes not only NASA and NOAA, but all the federal science agencies within the jurisdiction of the Appropriations Subcommittee on Commerce, Justice, Science, and Related Agencies, on which I serve as the senior Democrat.

US citizens deserve to know what's happening to their environment from the agencies they rely on to do the research to keep them safe.

Barbara A. Mikulski

United States Senate, 503 Hart Senate Office Buildings, Washington DC 20510, USA

\section{Scientists should be heard, but not expect to set policy}

SIR - Your Editorial "Science under attack" (Nature 439, 891; 2006) and News story "US scientists fight political meddling" (Nature $439,896-897$; 2006), on friction between scientists and the Bush administration, impart a curious and unwarrantedly broad meaning to the term 'unitary executive' with reference to the US polity. In fact, the term stems from the first sentence of Article II of

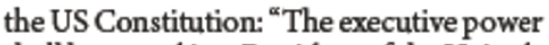
shall be vested in a President of the United States of America. Our president has sole ('unitary') constitutional power to run the executive branch, and also sole responsibility for all its actions. As Harry Truman put it when he was in office, "The buck stops here." Unitary executive power does not infringe on the legislative or judicial powers of other branches of government.

The problem that has arisen between the administration and the scientific community is how the notion of presidential executive power is to be extended (or not) to scientific employees of the multitudinous departments and agencies of the executive branch, and in particular to their strictly scientific opinions (to the extent that those can be separated from policy conclusions). The constitution does not clarify this point, because its authors did not foresee how large the executive branch would eventually become. The issue is neither easy nor trivial, for government scientists have many opinions (some opposed or contradictory), but no independent authority and no responsibility for public policy.

The climate of the present dispute would benefit if both sides would tone down the rhetoric and ease back on the partisan throttle. No administration can gain much by ignoring or silencing the best scientific advice available, either within or outside the government. On the other hand, unelected government scientists in the civil service are not independent political players, and have no inherent licence to make pronouncements designed to call established public policy into question. We govern ourselves primarily through elected officials and their appointees, not by scientific consensus — be it wise or foolish.

William R. Dickinson

Department of Geosciences, University of

Arizona, Tucson, Arizona 85718, USA

\section{Fraud: anonymous 'stars' would not dazzle reviewers}

SIR - In the current discussion about fraud (see Correspondence, Nature 439, 782-784; 2006), the important issue of what actually makes people cheat in the first place has not been addressed. Whether an individual cheats and lies is dependent on many factors, but instant personal advantage is the central one.

Unlike nanotechnology and genetics research, where lucrative patents can beckon, my field of Earth sciences has little to offer but basic research in public institutions. The pressure on the relatively few permanent jobs available to a growing number of scientists in this field is therefore high, and hence the rewards of publishing in the highest-ranked journals are extremely significant for one's career. The temptation to fumble with the data a bit for the sake of the story, or to include a big-shot author as a showcase, is understandable.

In the most notorious recent cases (the Korean stem-cell work and Jan Hendrik Schön's nanotechnology work), the peerreview system must be said to have failed, as the frauds were unveiled by people from outside the immediate process. Were the referees the weakest link, and were both the editors and the referees blinded by the aura of the authorships?

Despite some disadvantages, anonymous peer-review remains the fairest way to prevent publication bias (see "Three cheers for peers"
Nature 439,$118 ; 2006)$. But who ensures the quality of the referees and the refereeing process? Clearly, it is the editor's responsibility to overlook lobbying by authors and referees alike and to improve procedures if necessary to ensure fair assessment of all submissions, not favouring those from 'star' authors.

I believe it is best for the publisher not to reveal authors' names or affiliations to the referee until the submitted manuscript has been accepted or finally rejected. Withholding the authors' identities in this way will not only ensure high quality, but will stop rejected authors from believing that their submission had been treated unfairly compared with those of 'star' authors.

Henning Bauch

Akademie der Wissenschaften und der Literatur, Mainz c/o IFM-GEOMAR, Leibniz-Institut für Meereswissenschaften, Wischhofstrasse 1-3, 24148 Kiel, Germany

\section{Research skewed by stress on highest-impact journals}

SIR - Emilio Artacho, in Correspondence ( ${ }^{\circ}$ Reader-appeal should not outweigh merit

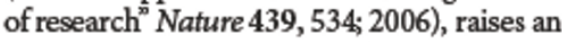
important point concerning the growing tension between merit and appeal of research, and alludes to the increasing pressure on young scientists to publish in journals such as Nature. This seems to have arisen from senior administrators, both at universities and at funding bodies, requiring simplistic measures of esteem such as numbers of Nature papers and citation rates. It creates problems in appointments, tenure and promotions, particularly for sciences that do not traditionally publish in Nature or have small communities and thus lower citation rates. As a result, many science departments are now skewed towards research that appeals to the more general reader.

I am pleased that a number of the UK Research Assessment Exercise panels have stated that they will judge papers submitted to them, not on the basis of where they have been published, but rather on their inherent impact and importance. If we want to relieve some of the pressures on young scientists and create a more balanced science community, then we need to re-educate ourselves, and our senior university administrators, so that publishing in journals such as Nature, though important, is recognized as just one of a rich variety of research outputs.

Mark Maslin

Department of Geography, University College Landon, Landon WCIH OAP, UK

Contributions to Correspondence may be submitted to corres@nature.com. They should be signed by no more than three authors; preferably by one. 